\title{
Socio-Economic Characteristics of Registered Cocoa Farmers in Edo State, Nigeria
}

\author{
*1OSARENREN, CO; ${ }^{2}$ EJUETUEYIN, JO; ${ }^{3}$ EWEKA KI
${ }^{1}$ Department of Agricultural Extension and Management, Edo State College of Agriculture, Iguoriakhi, P.M.B 147,Benin City, Edo State, Nigeria. E-mail: chris.osarenren@yahoo.com
${ }^{2}$ Department of Agricultural Economics and Extension Services, Faculty of Agriculture and Agricultural Technology, Benson Idahosa University, Benin City, Edo State Nigeria.
${ }^{3}$ Department of Agricultural Education, college of Education, Ekiadolor Benin. PMB 1144

\begin{abstract}
This study examined the socio-economic characteristics of registered cocoa farmers in Edo State; Nigeria. Primary data was collected using a well-structured questionnaire administered to 180 registered cocoa farmers selected using a multi-stage sampling technique. Data were analyzed using descriptive statistics and budgetary technique. Results showed that $88.9 \%$ of cocoa farmers were male with a mean range of 46 years with $75 \%$ being married and $88.8 \%$ having formal education. The budgetary technique was used to determine the profitability of cocoa production, which was found to be profitable in the study area at a gross margin of $\mathbf{N 6 6 \text { , }}$ 350, Net Farm Income of $\mathbf{N 5 9}, 200$, and net return on investment of $\mathbf{N}$ 1.11.The Benefit Cost Ratio and Expense Structure Ratio of 2.11 and 0.12 respectively indicated that cocoa production was economically profitable and viable since the BCR is greater than 1 and the Gross Ratio (GR) of cocoa production is 0.47 . From these profitability ratios, it shows that cocoa production is a profitable business in the study area. Inadequate finance to operate on large scale was found to be the major constraint to the cocoa farmers in the study area. The study concludes that cocoa production is profitable and was recommended that production could be improved and sustained through provision of soft loans to the farmers. () JASEM
\end{abstract}

\section{http://dx.doi.org/10.4314/jasem.v20i2.5}

Key words: socio-economics, characteristics, registered cocoa farmers.

Cocoa product is highly valued by most farmers in Edo State as it provides them with the means of earning a living. Cocoa discovery and cultivation has brought a new dimension to the world economy. Cocoa is an international commodity which has played a pertinent role in the economies of the countries mostly the developing countries in Africa. It is traded in the international exchange market in two world currencies; the Great Britain Pounds and the United State Dollars (WCF, 2009).

Commercial cocoa farming is one of the most important agricultural activities in tropical West Africa. Over the years; it has improved on the living standards of farmers just as it stands as major foreign exchange earner for many West African countries. Cocoa farmers worldwide depend on cocoa for their livelihood with an annual world production of three million tonnes (WCF, 2009).

Cocoa is dependent on natural resources and unskilled or semi-skilled low cost labour rather than technology as the dominant portion of its total cost. (Bedford2002).The dominance of smallholders in the cocoa production sector and the lack of farm labor due to increased rate of urbanization held back production.
Nigeria has the potential to produce over 300,000 tons of cocoa beans per year, but production only amounted to 145,000 tons in 1999 (Nigeria Agriculture Stats, 2014).

Unlike large, industrialized crops, $80 \%$ to $90 \%$ of cocoa comes from small, family-run farms, with approximately five to six million cocoa farmers worldwide. In Africa and Asia, the typical farm covers two to four hectares (five to ten acres). Each hectare produces 300 to 400 kilograms of cocoa beans in Africa and about 500 kilograms in Asia. Cocoa farms in the America tend to be slightly larger and produce 500 to 600 kilograms of cocoa beans per hectare. Yield per hectare varies not only by region, but also by country and by type of cocoa (WCF, 2014).

International Cocoa Organization (ICCO, 2014) highlighted the twelve top cocoa-producing countries in order of annual production size at present are Côte d'Ivoire, Ghana, Indonesia, Nigeria, Cameroon, Ecuador, Brazil, Peru, Dominican Republic, Colombia, Papua New Guinea and Mexico.

The WCF (2009) postulated that 5-6 million cocoa farmers exist worldwide and added that the total world 
production of cocoa is (about 3.7million tonnes) of which $90 \%$ is from small scale cocoa farms run by families with outdated farm practices and limited access to inputs. Their farm sizes range between 2 and 5 hectares. While about 40 and 50 million people globally depend on cocoa for their livelihoods (WCF, 2009).

According to ICCO (2014) report, the total world consumption of cocoa was estimated to be 4.01 million tones; this amount is slightly below 4million tones production for the period. Europe would likely continue to be the world's largest consuming area with about $47 \%$ of the global share of consumption, while all the developing countries put together would account for 1.3 million tones on the consumption scale. And these countries include Africa, Latin America, North America and Far East (ICCO, 2014). The study therefore seeks to answer the following research questions; what are the socio-economic characteristics of the cocoa farmers in the study area? How profitable is cocoa production among registered cocoa farmers in Edo State? Do the cocoa farmers face production challenges? The objective of this study was to examine the socio-economic characteristics of registered cocoa farmers in the study area with a view to finding ways to sustain the increase in cocoa production for food security and income generation.

\section{MATERIALS AND METHOD}

Study Area: The study was carried out in Edo State, Nigeria. The State is bounded in the North by Kogi State, in the East by Anambra States, on the South by Delta State, on the West by Ondo State. The primary data were collected by means of structured questionnaire and interview schedules administered to one hundred and eighty (180) cocoa producers selected for the study. On the other hand, the secondary data were obtained from relevant publications. The data collected include the socioeconomic characteristics of the cocoa producers (such as age, sex, marital status, household size, years of schooling, years of experience in cocoa production), the input and output data [consisting of farm size (ha), family and hired labour (man-days), fertilizers $(\mathrm{kg})$, bean harvested $(\mathrm{kg})$ and market prices of all inputs employed in production and output] as well as the perceived problems of respondents affecting the economic production of cocoa in the study area.

Data Analysis: Data collected were analyzed using descriptive statistics such as frequency counts, means and percentages as well as the gross margin analysis. The gross margin analysis is presented as:

$$
G M=(\mathrm{TR}-\mathrm{TVC})
$$

Where, $\mathrm{GM}=$ Gross margin; $\mathrm{TR}=$ Total Revenue; TVC $=$ Total Variable cost

Net Farm Income Analysis:

$$
N F I=G M-T F C
$$

Where; NFI $=$ Net farm income per hectare $(\mathrm{N})$, and TFC is Total fixed cost which includes cost of hoes, cutlasses, wheel barrow, knapsack, files, pick axes and land.

\section{Return per Naira Invested:}

$$
R I=\mathrm{GM} / T V C
$$

Where; RI = Return per naira invested, $\mathrm{GM}=$ Gross margin, $\mathrm{TVC}=$ Total Variable Cost

The straight line depreciation method was used to determine the actual value of the fixed cost of the assets during the production season.

$$
D=\frac{C-S}{N}
$$

Where: $\mathrm{D}=$ Depreciated amount, $\mathrm{C}=$ Initial cost of the assets, $\mathrm{S}=$ Salvage value, $\mathrm{N}=$ Expected number of useful life span. The salvage value was assumed to be zero.

The performance and economic worth of the respondents were determined by the use of the following profitability and viability ratios:

$$
\begin{gathered}
\text { Benefit Cost Ratio }(B C R)=\frac{\text { Discounted } T R}{\text { Discounted } T C} \\
\text { Expense Structure Ratio }(E S R)=\frac{F C}{V C} \\
\text { Rate of Return (ROR) }=\frac{N R}{T C} \\
\text { Gross Ratio }(G R)=\frac{T C}{T R}
\end{gathered}
$$

\section{RESULTS AND DISCUSSION}

The socio-economic characteristics of the registered cocoa farmers in the study area are presented in Figures 1-6. The result indicated that $66.7 \%$ of the cocoa farmers were within the age range of $41-50$ years with a mean age of 46 years. This shows that respondents were in their middle ages which implied that cocoa farmers were still in their economic active age and would result in positive effect on production. 
The gender distribution shows that majority of the respondents where predominantly males accounting to $88.9 \%$ of the respondents while the females only accounted for $11.1 \%$ (Fig. 1). This also portrays the role of women in farm management decision making process as they often play a minimal part in making economic decisions which affect them directing or indirectly (Damisa and Yohanna, 2007). This indicates that in cocoa production the role of the women is often confined to post harvesting handling which includes fermentation and drying. Most of the respondents were married (135 respondents) accounting for about $75 \%$ of the respondents in the study area with $5.6 \%$ and $2.8 \%$ divorced and widows respectively, while $16.7 \%$ were single. The implication of this is that farmers in the study area were mature and could effectively take crucial decisions jointly with their spouses. Wives are still used for supportive operations in farm operations. With respect to education, about $88.8 \%$ of the respondents had formal education while $11.1 \%$ of them had no formal education. This implies that majority of the cocoa farmers attended secondary school and such were fairly educated. This does not differ from earlier findings of Oluyole (2005) who reported that high literacy level will enable farmers to understand the intricacies of factor and product market and also predispose them to adopt and use improved farm practices. A high level of literacy might positively influence the farm business. The mean household size of seven implies a fairly good family labour particularly in a situation where labour availability is mainly family size dependent. This implies that the farmers have a fairly large household which could probably serve as an insurance against short falls in supply of farm labour. Majority $(61.1 \%)$ of the cocoa farmers in the study area had farming experience ranging between $11-20$ years. The relative high number of experienced farmers suggested that cocoa production is an ensuring occupation. Continuous practice of an occupation for a long period presumably makes a person more experienced and more productive in practice (Adeoti, 2004). About $90 \%$ of the respondents did not have more than 10 hectares of cocoa farm while only $10 \%$ had more than 10 hectares. This implies that majority of the respondents were small scale farmers. This agrees with the findings of Ogunlade et al (2009) which reported that $75.5 \%$ of the cocoa farmers in Nigeria were either small or medium scale farmers. This could be attributed to the fact that small scale farming largely dominates the agricultural sector in Nigeria.

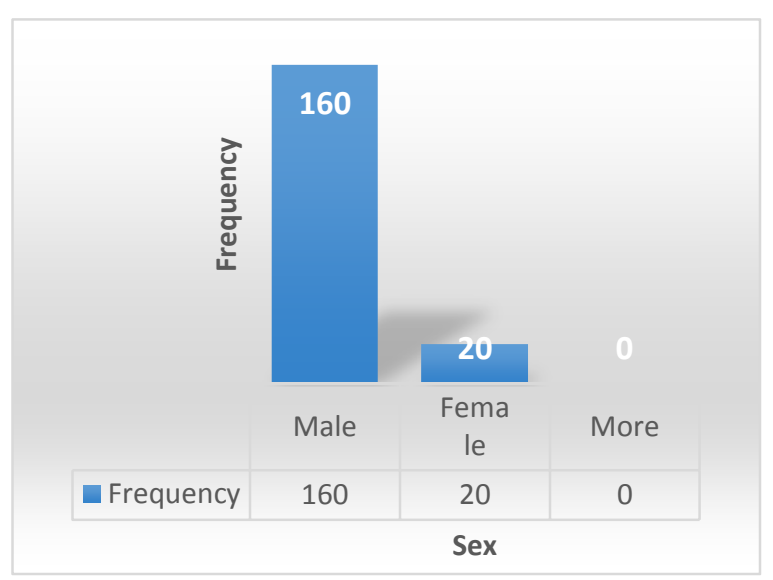

Fig.1: Histogram showing sex distribution of respondents

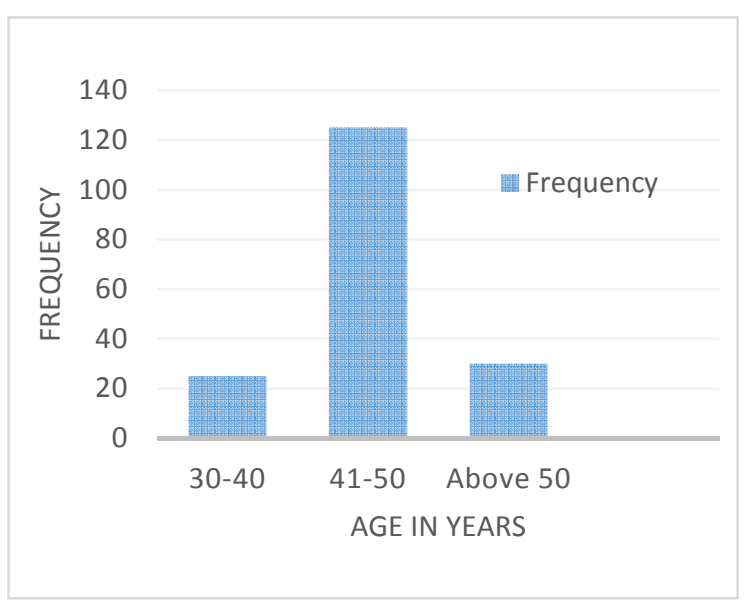

Fig.2: Histogram showing the age distribution of farmers

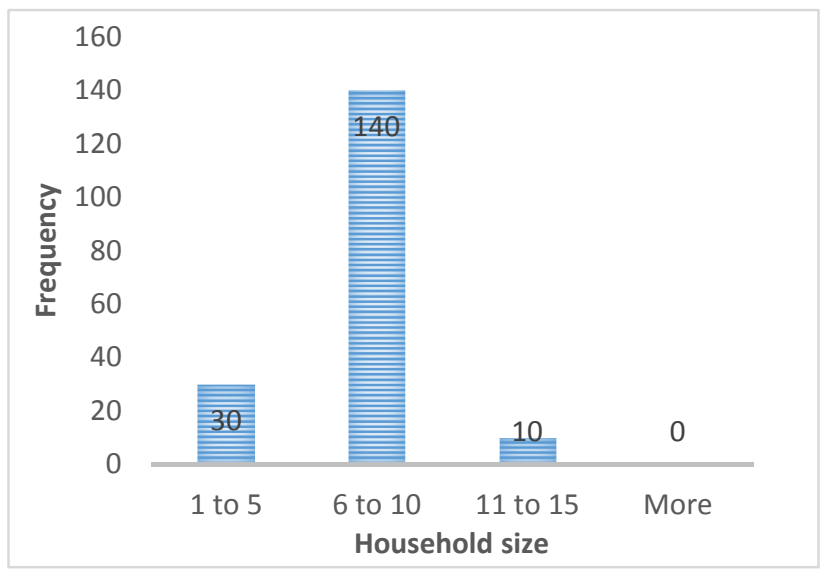

Fig. 3: Histogram showing the marital status of the respondents 


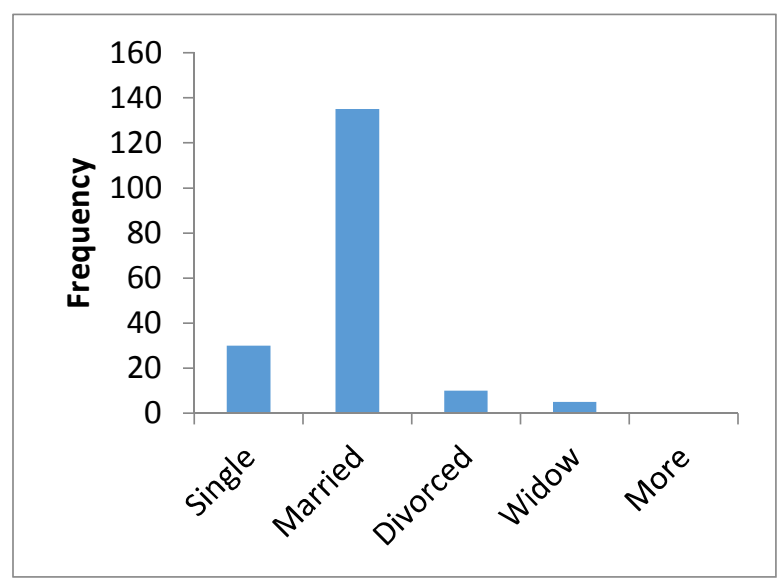

Fig. 4: Histogram showing the educational level of the farmers

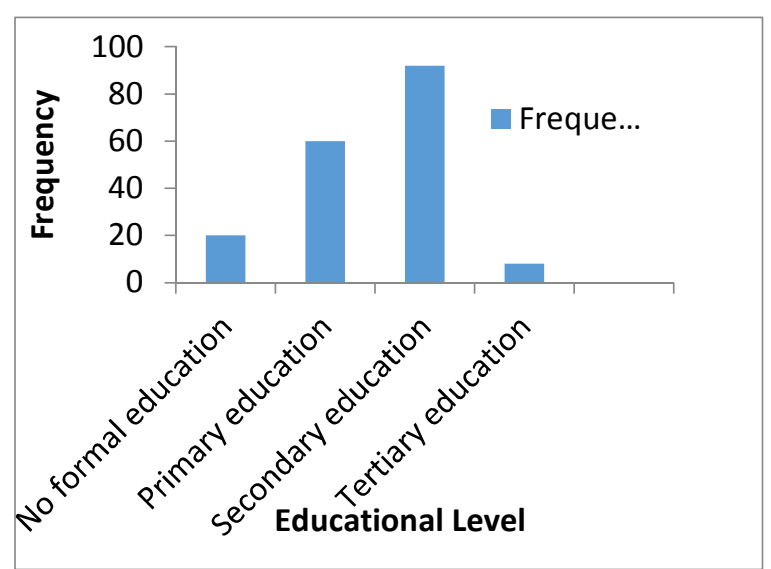

Fig. 5: Histogram indicating the household size of respondents

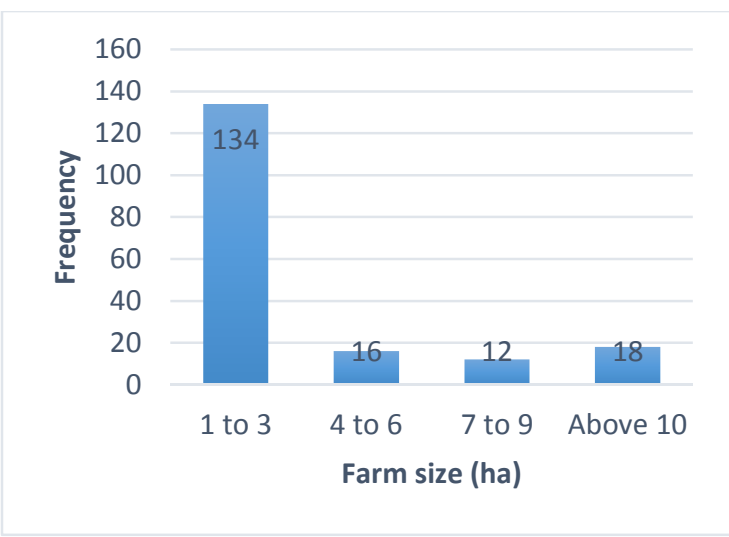

Fig. 6: Histogram showing the farming experience (years) of respondents
The profitability of cocoa productions in Edo state was estimated using costs and returns analysis as presented in Table 1. The Table shows that labour constituted $37.55 \%$ of the total variable cost while the percentage share of total variable cost for agrochemical, transportation, jute bags and miscellaneous were $31.01 \%, 16.18 \%, 4.02 \%$, and $11.23 \%$ respectively. Labour cost took the largest component of total variable cost. The cost and return analysis also showed the gross margin of N66, 350 .

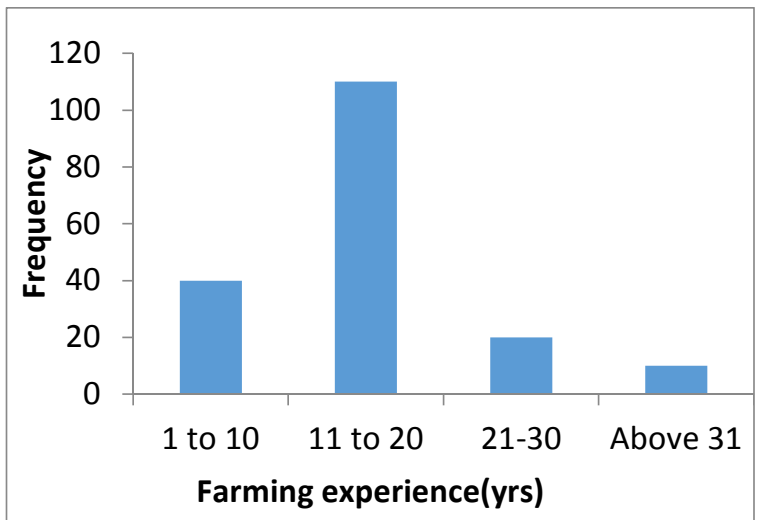

ig. 7: Histogram indicating the farm size of the respondents

Table 1: Estimate Cost and Returns Cocoa Production per Hectare in the Study Area.

\begin{tabular}{lll}
\hline Items & $\begin{array}{l}\text { Amou } \\
\mathrm{nt}\end{array}$ & Percentage \\
\hline Revenue from the sales cocoa & 126, & \\
produce & 000 & \\
Variable cost & & \\
Labour cost & 22,400 & 37.55 \\
Agrochemical & 18,500 & 31.18 \\
Transportation cost & 9,650 & 16.18 \\
Jute bags & 2,400 & 11.23 \\
Miscellaneous & 6,700 & 4.02 \\
Total Variable cost & 59,650 & 100 \\
Fixed cost & & \\
Rent on land & 4,000 & 55.94 \\
Depreciated cost on farm & 3,150 & 44.06 \\
Implement & & \\
Total fixed cost & 7,150 & 100 \\
Gross margin & 66,350 & \\
Net Farm Income & 59, & \\
& 200 & \\
\hline
\end{tabular}

Source; Field survey, 2016

The Benefit Cost Ratio (BCR) is one of the concepts of discounted method of project evaluation. As a rule of thumb, Benefit Cost Ratio greater than one indicates profit, equal to one indicate break-even and less than one indicates loss. Since the ratio is greater than one this shows profit and indicates that cocoa production 
in the study area is profitable even with little capital invested into it. It is possible to have higher value of BCR with increased capital and skilled labour. The Rate of Returns (ROR) for Cocoa Production in Edo State is 1.11 . This shows that for every N 1.00 invested in cocoa production, an additional of 1.11 kobo would be gained by the cocoa farmers in the study area. The Expense Structure Ratio (ESR) was 0.12 which implies that $12 \%$ of the total cost of production is made up of fixed cost component. The Gross Ratio is 0.47. This implies that for every 1 return to cocoa farmers, $\$ 47$ was spent in the study area. From these profitability ratios, it shows that cocoa production is a profitable business in the study area.

Table 2: Profitability Ratio

\begin{tabular}{cc}
\hline & Mean \\
\hline Benefit Cost Ratio (BCR) & 2.11 \\
Expense Structure & 0.12 \\
Ratio(ESR) & 1.11 \\
Rate of Returns & 0.47 \\
Gross Ratio (GR) & \\
\hline
\end{tabular}

Source: Field survey, 2016

Table 3 shows the constraints faced by cocoa farmers in the area. The most serious was inadequate finance with a mean of 4.91 and a standard deviation .36. This was followed by inadequate storage and inadequate processing facilities as major constraints with the mean values of 4.74 and 4.44 respectively. Also high cost of labour, lack of access to machine, inadequate access to agrochemical, fluctuating price of produce, high cost of transportation, and standardization were identified as minor constraints in cocoa production in the study area

Table 3: Constraints Faced By Cocoa Farmers in the Study Area

\begin{tabular}{lcc}
\hline Constraints & $\begin{array}{l}\text { Mean } \\
\text { value }\end{array}$ & $\begin{array}{c}\text { Standard } \\
\text { deviation }\end{array}$ \\
\hline Inadequate finance & 4.91 & .36 \\
Incidence of pest & 4.74 & .62 \\
Inadequate storage & 4.47 & .87 \\
Inadequate processing & 4.44 & .92 \\
facilities & & \\
High cost of labour & 4.20 & .81 \\
Lack access to machine & 4.05 & 1.15 \\
Inadequate access to & 3.89 & .96 \\
agrochemical & & \\
Fluctuating price of produce & 3.70 & .93 \\
High cost of transportation & 2.15 & .83 \\
Standardization & 2.35 & .87 \\
\hline
\end{tabular}

Source; Field Survey, 2016

Conclusion: Conclusively, it can be seen that majority of cocoa production was predominantly practiced by males and still in their productive years. The profitability analysis indicated by Gross Margin, Net Farm Income value, Benefit Cost Ratio, Expense Structure Ratio and Rate of Returns showed that cocoa production in the study area was highly profitable and economically viable. From research findings, it is recommended that more people should be empowered and encouraged to go into cocoa production so as to ensure food security in the nation and to improve family livelihood, Soft loans with little or no interest rates should be provided for the cocoa farmers, since most of the farmers are small holder, they should be encouraged to acquire more land in order to increase their yield and profits

\section{REFERENCES}

Adeoti, A. I. (2004). Impact of HIV/AIDS and Related Sickness on the Technical Efficiency of Farms in Benue State, Nigeria. Issues in African Rural Development Monograph Series, Monograph 434.

Bedford, K. (2002). Value Chains: Lessons from the Kenya Tea and Indonesian Cocoa Sectors.

International Business Leader Forum / Natural Research Institute

Damisa J. S and M. Yohanna (2007). Role of Rural Women in Farm Management Decision making process: Ordered Probit Analysis. World Journal of Agricultural Science 2(4): 543- 536.

International Cocoa Organization, ICCO (2014). International Cocoa Organization Regional Seminar on the functioning of cocoa futures markets and Econometric Modelling of the cocoa market. Indonesia, July 2014.

Nigeria Agriculture Statistics. (2014). The Nigeria agriculture profiles (subcategories).

Retrieved from: /www.nationmaster.com/countryinfo/profiles/Nigeria/Agriculture.

Ogunlade, M. O., Oluyole K.A. and Aikpokpodion, P.O. (2009). An Evaluation of the Level of Fertilizer Utilization for Cocoa Production in Nigeria. Journal of Human Ecology. 25(3): 175178.

Oluyole, K.A. (2005). Evaluation of the Economics of Post Harvest Processing of Cocoa in Cross River State, Nigeria .Journal of Agriculture, Forestry and the Social Sciences. 3(2): 58 - 64.

World Cocoa Foundation (WCF) (2009) .Encouraging Sustainable Responsible Cocoa 
Growing.www.worldcocoafoundation.com/cocoa factsandfigures.

World Cocoa Conference (2014). Ensuring a sustainable cocoa value chain to guarantee quality supply and enable future growth, Amsterdam, the Netherlands. $\quad 9-13^{\text {th }} \quad$ June 2014. www.worldcocoaconference.org. 